\title{
鉄鋼の粒内フェライト変態に及ぼす $\mathrm{Mn}$ 欠乏層形成の効果
}

\author{
新日本製鐵株式会社先端技術研究所 重里元一* 杉山昌章* \\ 新日本製鐵株式会社鉄鋼研究所 植 森 龍 治**
}

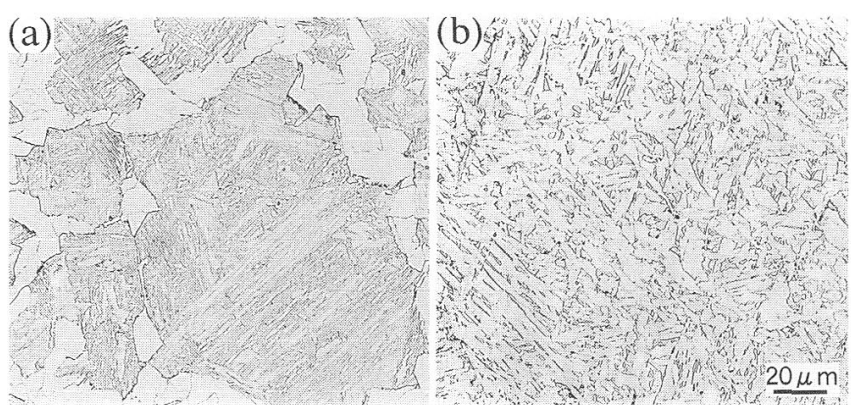

Fig. 1 光顕観察像. (a) $1673 \mathrm{~K} \rightarrow 823 \mathrm{~K}$ (鋼 A), (b) $1673 \mathrm{~K} \rightarrow 1373 \mathrm{~K} \rightarrow 823 \mathrm{~K}$ (鋼 B).

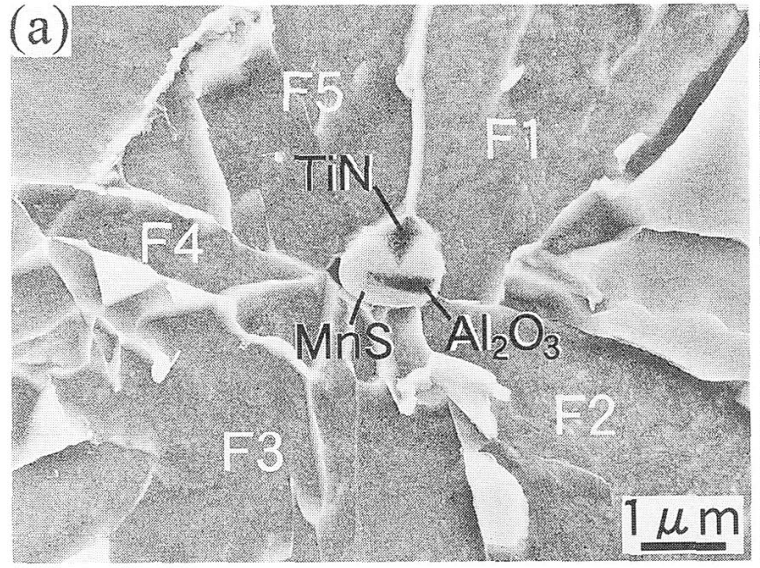

Fig. 2 介在物を変態起点として生成した $\alpha$ 結晶粒.

鋼の溶接熱影響部 (HAZ) では結晶粒が粗大化し勒 性が低下寸る。このような HAZ 勒性低下の抑制に粒 内フェライト (Intra Granular Ferrite: IGF)変態を利 用することができる。これは，鋼中の介在物をオース テナイト $(\gamma) \rightarrow$ ェライト $(\alpha)$ 変態の変態核生成サイ トとして活用することで $\alpha$ 結晶粒を微細化する技術 である (1). IGF 変態核生成サイトとなっていること を確認した介在物を集束イオンビーム (FIB)加工法に より薄片化し ${ }^{(2)}$, TEM-EDS 分析により IGF 変態に 物ける Mn 久乏効果を調べた。

$0.02 \mathrm{C}-1.5 \mathrm{Mn}-0.003 \mathrm{~S}$ (mass\%) 鋼老 $1673 \mathrm{~K}$ K加熱 後, 直接 $823 \mathrm{~K}$ 末で急冷し変態させた鋼 $\mathrm{A}$ と, 一旦 $1373 \mathrm{~K}$ で $100 \mathrm{~s}$ 保持し既存の MnS を析出成長させ た後 $823 \mathrm{~K}$ まで急冷し变態させた鋼 B に括いて組織 の違いを調べた(Fig. 1). 鋼 A では $\gamma$ 粒界のみから $\alpha$ 粒が生成しているが，鋼Bでは $\gamma$ 粒内からも $\alpha$ 粒が

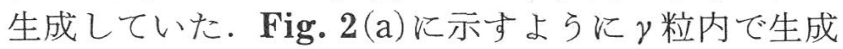

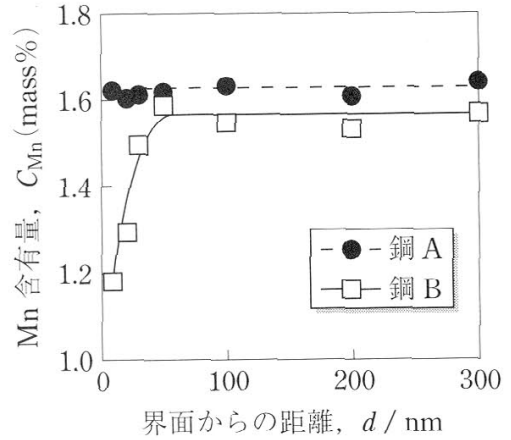

Fig. $3 \mathrm{MnS} /$ 鋼界面付近の鍼中 $\mathrm{Mn}$ 濃度分布。

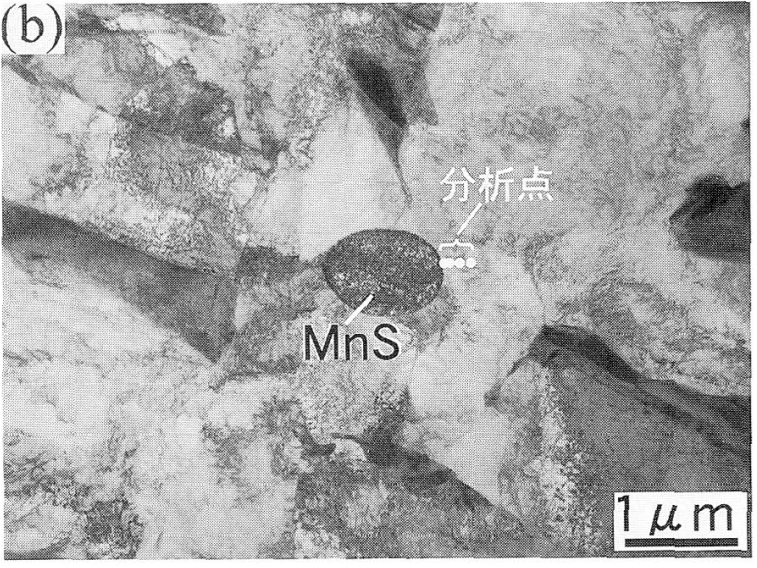

(a) SEM 像, (b) TEM 像.

した $\alpha$ 粒は $\mathrm{Al}_{2} \mathrm{O}_{3}+\mathrm{TiN}+\mathrm{MnS}$ 複合介在物を起点と して生成していた。 Fig. 2(b)はこの複合介在物を FIB 加工法で薄片化し TEM 観察したもので西る。 ただし, 薄片化加工の際に TiN, $\mathrm{Al}_{2} \mathrm{O}_{3}$ は除去された。 Fig. 3 K MnS 周辺の鋼中 Mn 濃度測定結果を示与。 鋼 $\mathrm{A}$ でも溶鋼中で晶出した MnS が存在したが Mn 欠乏層は形成されていない。1373 K で MnS を析出 成長させることで明らが MnS 近傍の Mn 濃度が低 下している(鋼B).Mn $\mathrm{Mn}$ が欠乏した領域 (Mn 欠乏層)が IGF 変態の主要な 核生成サイトになり得るといらことを実用鋼に物いて 実訨できた。

\section{文献}

（1）間㴊秀里，栗飯原周二：まてり山，34(1995), 301-305.

（2）重里元一, 杉山昌章, 植森龍治, 寺田好男 : CAMP-ISIJ, 12 (1999), 534.

（2000年 8 月 14 日受理）

Effect of Mn Depletion on Intra-Granular Ferrite Transformation from Austenite in Steel; Genichi Shigesato*, Masaaki Sugiyama*, Ryuji Uemori**(*Advanced Technology Research Lab., Nippon Steel Corp., Futtsu. **Steel Research Lab., Nippon Steel Corp., Futtsu) Keywords: low alloy steel, intra-granular ferrite transformation, toughness, manganese depletion TEM specimen preparation: Focused Ion Beam fabrication TEM utilized: HF-2000 (200 kV) 